\section{What to believe of science}

SIR - Nature has exposed two enemies of the eternal verities, George Walden and Bryan Appleyard (356, 729; 1992). I can do no better than to quote from the graduation address of 22-year-old Herbert M. Evans in Berkeley, 1904.

Why not then limit scientific and in particular biological research to problems sure of a practical outcome? Were not such a question sometimes seriously asked there would be no need of answering it

Nothing in all our evolution toward civilized life is now so well established as the fact that pure research must proceed, and is the mother of applied science. Man must know natural laws widely and generally, before we can harness them for human use. To fail to recognize the scientific fountainhead of our information would be to limit forever the conceptions of the human mind, to draw around it a fixed horizon. .

Through a purely theoretical interest in the structure of the sugar molecule, the great Pasteur was led to the brilliant investigations of fermentation which had so great a practical bearing on the industries of France.

So it has been in every science. . .

Thomas H. Jukes

University of California, Berkeley,

6701 San Pablo Avenue,

Oakland, California 94608, USA

SIR - Does science leave room for soul? Yes, of course it does and only those with a most surperficial reading of the bangs-and-stinks-and-big-machines could think otherwise. One 'purpose' of science is to allow us to see and to understand the underlying beauty of the organization of reality. It is only those who have not seen or who cannot understand this beauty who think science soulless, or who insist on calling the Universe a machine; if it is, it is a soft machine.

If Appleyard asks for a common belief in something, why not a common belief in reality? I know that reality, often being both stranger and more interesting, can be harder to believe in than your common-or-garden miracle, but can belief in an intangible be counted purposeful? What if there is a supreme being whom I choose to believe in? Has it or anyone's belief in it relieved, for example, the suffering Bosnians? I may as well believe in fairies.

And finally, to social violence and damnation. It takes a truly perverse, if politically quotable, reading of world history to cite today as an especially socially violent time. Have not many of the most horrific examples of social violence coincided precisely with the highest 'social awareness' of eternal damnation? Bless the Crusaders, the Conquistadors, the Germans of the Nazi era, the church-going slave-traders, not to menNATURE · VOL 358 - 23 JULY 1992 tion the Spanish Inquisition. The religious, purposeful, soulful mechanics of untold abominable deaths. Believers.

Let science then erode such belief.

Simon L. Goodman

MPG Gruppen für Rheumatologie,

Schwabachanlage 10,

D-8520 Erlangen,

Germany

SIR - It is amazing to read in Nature a virulent attack on Appleyard's book seen as a reinforcement of belief in opposition to science, and, two pages later, to find the word "doctrine" applied to the Big Bang hypothesis. Is science presenting itself as a new religion, adopting the appropriate vocabulary? This example can only comfort those who, like Appleyard, think so.

J. M. Gillis

Department of Physiology

University of Louvain, Belgium

\section{Marine explosions}

SIR - Your report on the postponement of a marine explosion planned to have been carried out in Cardigan Bay by the British Geological Survey (BGS, Nature 357, 183; 1992) does not, unfortunately, refer to the Agreement on the Conservation of Small Cetaceans of the Baltic and North Seas, which Britain has recently signed. The remarks attributed to me as a member of the Sea Mammal Research Unit should have been attributed to the interim secretariat for the agreement, which will be housed at this unit under my direction.

The agreement requires signatories to "work towards ... the prevention of ... significant disturbance (to small cetaceans), especially of an acoustic nature". Thus it would be unacceptable for organizations in Britain, Germany or Sweden (all of which have signed the agreement) to let off underwater charges without following some guidelines to minimize their impact on small cetaceans. The BGS had developed such a set of guidelines which was, I believe, within the spirit of the agreement.

This case has brought the potential effect of underwater seismic experiments on dolphins and porpoises to the public's attention. However, as your reporter points out, many other, much larger, detonations are carried out each year. I would encourage any organization contemplating such activity to contact the interim secretariat for the agreement for information on the potential risks to small cetaceans and how these may be reduced.

\section{Christina Lockyer}

Natural Environment Research Council,

Sea Mammal Research Unit,

c/o British Antarctic Survey,

High Cross,

Madingley Road,

Cambridge CB3 OET, UK

\title{
Fact and fiction in alignment
}

SIR - We have discovered a startling similarity between a dinosaur DNA sequence reported in the novel Jurassic Park $^{1}$ and a partial human brain cDNA



Our discovery also seems to raise the interesting legal question as to whether the copyright on Jurassic Park takes precedence over the pending patent on the human sequence. However, it appears that neither group is entitled to legal protection for its sequence, because both sequences also align with cloning vector pBR322, raising the

sequence from the Venter laboratory described in Nature ${ }^{2}$ (see figure). The dinosaur sequence (Dino1) consists of duplication, with 117 base pairs from the first member of the repeat aligning with the human sequence, HUMXT01431, at the 95 per cent level of identity with only two gaps. The extraordinary degree of nucleotide sequence conservation between organisms as distantly related as dinosaur and human suggests strongly conserved function. Expression of HUMXT01431 in human brain raises the possibility that the dinosaurs were smarter than has been supposed, arguing against the hypothesis that their extinction resulted from lack of intelligence. possibility that both groups inadvertently sequenced vector DNA.

Alan C. Christensen

Department of Biochemistry and Molecular Biology,

Thomas Jefferson University,

Philadelphia,

Pennsylvania 19107, USA

Steven Henikoff

Howard Hughes Medical Institute and Basic Sciences Division,

Fred Hutchinson Cancer Research Center,

Seattle, Washington 98104, USA

1. Crichton, M. Jurassic Park, 102 (Ballantine, New York, 1990).

2. Adams, M. D. et al. Nature 355, 632-634 (1992). 